\title{
Geomorphological and stratigraphic evolution of a fluvial incision in the coastal plain and inner continental shelf in southern Brazil
}

doi: https://doi.org/10.1016/j.margeo.2021.106514

url: https://www.sciencedirect.com/science/article/abs/pii/S0025322721000967

Authors: Eduardo G. Barboza, Sérgio R. Dillenburg, Renato P.Lopes, Maria Luiza C.C.Rosa, Felipe Caron, Vitor Abreu, Rogério P. Manzolli, José Carlos R.Nunes, Jair Weschenfelder, Luiz J. Tomazelli

\begin{abstract}
This paper describes the evolution of a sector of the southern coastal plain of the Pelotas Basin, southern Brazil, between the last Pleistocene sea-level lowstand and the Holocene highstand, based on geomorphology and high-resolution stratigraphy. A fluvial drainage system associated with an incised valley developed during the Last Glacial Maximum (LGM) was identified. Two highresolution 2D and 2.5D geophysical profiles using Ground-Penetrating Radar (GPR) show a Pleistocene fluvial system's former path, starting close to its present mouth inside Mirim Lagoon crossing the coastal barriers and reaching the inner continental shelf, covering some $60 \mathrm{~km}$ across the coastal plain. During the LGM, with the sea-level at -120 to $-130 \mathrm{~m}$ and the coastline positioned close to the shelf edge (distant $200 \mathrm{~km}$ from the present coastline), the fluvial system excavated a 31.5-m deep channel. Two cores, 36 and $32 \mathrm{~m}$ long, show that the paleochannel was filled with sedimentary deposits after $19.4 \mathrm{ka} B \mathrm{~B}$, and the facies succession represents the transition from fluvial, to estuarine, to the coastal barrier, and finally to inner shelf depositional environments, generated by processes connected to LGM and the Postglacial Marine Transgression (PMT). The study region behaved as a sediment by-pass zone, connecting the adjacent coastal plain's inner portion with the inner continental shelf. The studied area presents an unusual record of the LGM at a coastal plain domain.
\end{abstract}

\section{Keywords}

Taim swamp, Paleo-drainage, Mirim Lagoon, Holocene/Late-Pleistocene 